Разом 3 тим викладачі у відповідях назвали прізвища радянських педагогів XX ст.: I. Я. Лернера, що досліджував основи дидактики, написав багато праць про методи навчання, обгрунтував сучасні підходи в навчанні; М. М. Скаткіна, що займався методологією педагогічної науки, вдосконаленням процесу й змісту навчання, досліджував проблеми дидактики.

Окрім того експерти підкреслили значимість праць польського педагога В. Оконя, який досліджував фундаментальні основи навчального процесу, писав праці про історію школи, досліджував особливості проблемного навчання, автором педагогічного словника.

Отримані результати опитування свідчать про те, що в процесі викладання педагогічних дисциплін необхідним $є$ вивчення пріоритетних напрямів наукових шкіл - як вітчизняних, так і зарубіжних, які зробили вагомий внесок у науку та не втратили своєї актуальності сьогодні, а також новітні підходи в навчальному та виховному процесі, що впливатимуть на формування основ професіоналізму майбутнього вчителя.

DOI https://doi.org/10.30525/978-9934-588-80-8-1.63

\title{
ЗАБЕЗПЕЧЕННЯ ІНДИВІДУАЛЬНОГО ПІДХОДУ В ОСВІТНЬОМУ ПРОЦЕСІ ШКОЛИ ПЕРШОГО СТУПЕНЯ
}

\author{
Толмачова I. М. \\ кандидат педагогічних наук, дочент, \\ професор кафедри педагогіки, психології, початкової освіти \\ та освітнього менеджменту \\ Комунальний заклад «Харківська гуманітарно-педагогічна академія» \\ Харківської обласної ради \\ Шпитальна Н. С. \\ здобувач вищої освіти психолого-педагогічного факультету \\ Комунальний заклад «Харківська гуманітарно-педагогічна академія» \\ Харківської обласної ради \\ м. Харків, Украӥна
}

Основним вектором розвитку сучасного світу є глобалізація, демократія, соціально-культурні перетворення. Успішний поступ України можливий за умови прогресу не лише соціально-економічних i політичних перетворень, а й забезпечення високого рівня культури та 238 
освіченості кожного громадянина. Відповідно до цих запитів, важливим завданням загальної середньої освіти стає розробка та створення ефективних умов організації освітнього процесу. Реформування української шкільної освіти передбачає й системне забезпечення індивідуального підходу в освітньому процесі школи першого ступеня.

Актуальність проблеми підтверджується суперечністю між важливістю реалізації індивідуального підходу в освітньому процесі початкової школи та недостатньою розробленістю сучасного змісту, умов, форм, методів та засобів забезпечення даного підходу.

Мета роботи: схарактеризувати педагогічні аспекти реалізації індивідуального підходу в освітньому процесі школи першого ступеня.

Отже, «освітній процес - це інтелектуальна, творча діяльність у сфері освіти i науки, що проводиться у закладі освіти (науковій установі) через систему науково-методичних і педагогічних заходів та спрямована на передачу, засвоєння, примноження і використання знань, умінь та інших компетентностей у осіб, які навчаються, а також на формування гармонійно розвиненої особистості» [2].

Одним із головних орієнтирів ефективності освітнього процесу $є$ реалізація індивідуального підходу. Індивідуальний підхід - принцип педагогіки, згідно з яким у навчально-виховній роботі з учнівською спільнотою досягається педагогічний вплив на кожну дитину, який грунтується на знанні іiі особистих рис, здібностей і умов життя [1, c. 305].

Л. Хомич виділяє основні компоненти, які характеризують змістове значення поняття «індивідуальний підхід» в освітньому процесі:

1. 3 психолого-педагогічної точки зору - організація навчання, яка заснована на створенні оптимальних умов для виявлення задатків, розвитку здібностей та інтересів кожного учня;

2. Із соціальної - цілеспрямований вплив на формування творчого, інтелектуального, професійного потенціалу суспільства;

3. 3 дидактичної - вирішення актуальних проблем школи шляхом створення нової стратегії навчального процесу [6, с. 114].

Зазначені компоненти доповнюють один одного i допомагають більш повно зрозуміти суть та багатовимірність поняття, яке розглядається, оскільки професійна педагогічна діяльність багатогранний об’єкт дослідження, який відображає існуюче розмаїття прояву специфічних особливостей освітньої діяльності.

Індивідуальний підхід в освітньому процесі поєднує виховання та навчання в єдиний процес допомоги, підтримки, соціально-педаго-

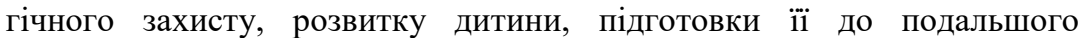
життєвого шляху. Основна мета полягає в тому, щоб всебічно вивчити 
дитину і своєчасно визначити позитивні якості в подоланні наявних недоліків. Це і $є$ характерними ознаками розуміння індивідуального підходу в освітньому процесі початкової школи.

Ми приєднуємося до думки О. Савченко, яка виділяє ряд завдань щодо реалізації індивідуального підходу в освітньому процесі: розвиток індивідуальних пізнавальних здібностей кожної дитини; поєднання виховання 3 самовихованням особистості; виявлення i усування причин, які можуть перешкодити досягненню мети; вміння діагностувати і знати реальний рівень сформованості таких важливих особистісних якостей, як спосіб мислення, мотиви, інтереси, ставлення до життя, ціннісні орієнтації; формування в особистості культури життєдіяльності, яка дає можливість правильно визначити лінії життя [5, с. 100]. Зауважимо, що ці завдання ставляться перед педагогом.

У рамках індивідуального підходу в освітньому процесі інакше осмислюється і зміст початкового навчання. Він перестає визначатися як передача здобувачам загальної середньої освіти знань, умінь, навичок, а розглядається як формування пізнавального інтересу, озброєння молодшого школяра вміннями самостійно здобувати знання, передбачає включення не тільки наукових знань, а й методів і прийомів пізнання.

На думку Н. Бібік, перед педагогом Нової української школи ставляться такі завдання:

1. Визначити життєвий досвід кожного учня, інтелектуальні здібності, інтереси, пізнавальні характеристики, які, в першу чергу, треба розкрити, а потім узгодити зі змістом освіти.

2. Мотивувати до пізнавальної діяльності, самовдосконалення та самореалізації в межах загальнолюдських цінностей.

3. Забезпечити учнів механізмами адаптації, самозахисту, саморегуляції та іншими якостями, які б виховували відповідальність за себе, за добробут нашої держави [4].

У результаті використання індивідуального підходу у вчителя створюється чітке уявлення про інтереси, характер, здібності кожного учня. Це дає змогу допомагати учням ліквідувати прогалини в знаннях, мотивувати молодших школярів до більш успішної роботі.

Основними інструментами вивчення індивідуальних особливостей школярів початкової школи є послідовні систематичні спостереження за учнями, індивідуальні та групові бесіди на підготовлені теми, додаткові навчальні завдання та аналіз результатів міркувань учнів.

Індивідуальний підхід в освітньому процесі передбачає існування індивідуально-рівноправних стосунків між вчителем та учнем, а також залучення до цього процесу особистісного досвіду (почуттів, емоцій, відповідних їм дій і вчинків) суб'єктів комунікації і спираються на 240 
застосування системи форм співробітництва. При цьому повинна дотримуватися певна умова партнерської взаємодії: від максимальної допомоги педагога учням у процесі вирішення навчальних завдань (дослідницьких проектів) до поступового зростання власної активності учнів, до повної саморегуляції в навчанні й появи відносин партнерства між ними. Перебудова форм співробітництва, пов'язана зі зміною позицій педагога й учня, «призводить до можливості самозміни суб'єкта навчання, що самостійно прокладає собі шляхи саморозвитку» [3, с. 35]. Важливо при цьому забезпечити певний алгоритм взаємодії: допомога вчителя школярам під час вирішення завдань повинна витікати у поетапне зростання особистої активності учнів. I, як результат взаємодії, повна саморегуляція в освітньому процесі, існування партнерства між учасниками.

Отже, індивідуальний підхід слугує засобом ефективного навчання, виховання та розвитку особистості здобувача загальної середньої освіти. Реалізація індивідуального підходу в освітньому процесі школі першого ступеня сприяе формуванню у молодших школярів позитивного ставлення до навчання, вміння працювати самостійно, забезпечує високу активність учнівської спільноти, впливає на підвищення результативності навчальних занять тощо.

Перспективами подальших наукових пошуків вважаємо розробку методичних підходів до забезпечення індивідуального підходу в ході викладання різних освітніх компонентів у початковій школі.

\section{Література:}

1. Волкова Н.П. Педагогіка : посібник. Київ : Академвидав, 2007. $616 \mathrm{c}$.

2. Про освіту : Закон України від 05.09.2017 р. № 2145-VIII (iз змінами № 725-IX). URL : https://zakon.rada.gov.ua/laws/show/214519\#Text

3. Коберник Г.І. Індивідуалізація й диференціація навчання в початкових класах : теорія та методика / Г.І. Коберник. К. : Науковий світ, 2002. 232 с.

4. Нова українська школа : порадник для вчителя / за заг. ред. Н.М. Бібік. Київ : Літера ЛТД. URL : https://nus.org.ua/wp-content/ uploads/2017/11/NUSH-poradnykdlya-vchytelya.pdf

5. Савченко О.Я. Дидактика початкової освіти. Київ : Генеза, 2002. $368 \mathrm{c}$.

6. Хомич Л.О. Система психолого-педагогічної підготовки вчителя початкових класів : дис. ... доктора пед. наук: 13.00 .04 / Л. О. Хомич. К: Магістр-S, 1999. 408 с. 